\title{
EFFECT OF TYPE OF PACKAGE AND STORAGE ON INSECT POPULATION OF Gibbium psylloids (ZEMP.), ON THE QUALITY AND QUANTITY OF DRY CHAMOMILE. Abo-Donia, S. A. ${ }^{\text {; }}$ Mona A. Magd El - Din ${ }^{2}$; M. Mettwally ${ }^{1}$ and
} Z. A. Attia ${ }^{2}$ 1 Plant Protection Dept., Faculty of Agriculture, Al-Azhar University. ${ }^{2}$ Plant Protection Dept., National Research Centre.

\section{ABSTRACT}

The effect of post harvest treatment and the hump beetle, Gibbium psylloids (Zemp.), on the quality and quantity of dry chamomile flower heads was studied. Results, after storage period of two years, revealed that the glass jar packing received the lowest insect population, followed by plastic net then card box, while the highest insect population was observed in polyethylene bag. The highest weight loss of dry chamomile flower heads occurred in plastic net and the lowest in glass jar, at the end of the second year of storage. The essential oil percentage decreased by increasing the storage period in all experimental packages. Acid number decreased in all package except in polyethelene bag, which recorded an increase in acid number after two years storage.

\section{INTRODUCTION}

Chamomile (Matricaria chamomilla L.) belongs to family Asteraceae and is one of the medicinal plants known for the longest time. Egyptian and Greeks knew the healing effects of the plant since thousands years. Its inflorescence and essential oil are also indispeusable in modern medicinal practice, it is an official drug in all the pharmacopoeias of the worlds. The infusion of the flower heads is an anti-infamniatory, antispasmodic and antiseptic as is well known. Its essential oil is used by the pharmaceutical industry to prepare. Anti- infamniatory medicines, and by cosmetic industry to prepare skin-care products. The use of this plant is significant all over the world. Egypt is one of the countries with the most extended production of chamomile. Most of the drugs appearing in the world market originates from Egypt and Argentine (Hornok, 1992).

Chamomile, Matricaria chamomilla L. is one of the most economic medicinal plants. Its flower heads are the main source of highly aromatic essential oil. Both the storage conditions and insect infestation are important in keeping the product in a good marketable quality (Rakova, 1961; Chinenova et al., 1969; Reffaat, 1988; Carle et al. 1989 and Waffa, 2001.

The hump beetle, Gibbium psylloids (Zemp.) is oftenly a minor insect and receives little attention as a storage products pest (Belles and Holstead, 1985; Lee et al. 1992; Salama and Ahmed 1995; Bosman and Jonge, 1998 and Waffaa, 2001). Therefore, the current investigation was conducted to study the influence of type package and storage on population density of $G$. psylloids on the quality and quantity of dry chamomile.

\section{MATERIALS AND METHODS}

Effect of type of package and storage period on insect population:-

After the harvest, the yield of chamomile flower heads were collected from the filed (Abo Gonsho - El Fayoum) and transferred to the laboratory. 
Under the laboratory conditions the yield was divided into two parts. After that it was stored in different containers which were made of glass, cloth, plastic or cellophane. The infestation by G. psylloides was carried out by using three pairs of adult stage for the first level and five pairs for the second level.

All containers (plastic, glass, cloth and cellophane) were kept under laboratory conditions throughout the storage period extending one year.

Three replicates $(25 \mathrm{gm})$ for each level of insect infestation of each package were done.

Samples were taken every three months of chamomile flower to follow up the development of insect population in each container.

\section{Effect of storage condition on the volatile oil of chamomile:}

In this experiments the flower heads of chamomile were air dried in the shads. Then stored in four different conditions; plastic, glass, cloth and cellophane with different three infestation level; not infestation, semi infestation and infestation. The different conditions were stored at room temperature for one year, each treatment was represented by three replicates.

The samples were taken every three months from chamomile. Chamomile flowers were taken from each treatment to extract and determine volatile oil .

volatile oil percentage:

Volatile oil percentage in flower head of chamomile sample from each treatment was determined using Clevenger apparatus as described by Guenther (1973). Twenty five grams of chamomile flowers were separately mixed with $500 \mathrm{ml}$ of water in a rounded one-liter flask and subjected for hydrolistillation for three hours. The resulted volatile oil was dried over unhydrous sodium sulphate and then stored in dark bottles at a refrigerator until used for analysis. The quantity of volatile oil was determined for each treatment to study the relation between the quantity of volatile oil containers and insect population.

GC/MS: Analysis were performed on a Hewlett-Packard Capillary Column $50 \mathrm{ml}$ carbowax, $20 \mathrm{~mm}$. Internal diameter $0.2 \mathrm{~mm}$, film thickness $0.33 \mathrm{~m}$., over temperature $\left(40\right.$ to $\left.200^{\circ} \mathrm{C}\right)$, program rate $\left(2^{\circ} \mathrm{c} / \mathrm{min}\right)$, Injection port temperature $\left(150^{\circ} \mathrm{c}\right)$, Detetor (TLC), carrier gas (Helium/ and Carried flow $\mathrm{ml} / \mathrm{min}$ ).

The components of the oil were identifified by comparison of their mass spectra with those of the camper library (Wiley) or with matching their retention times with those of autheutic samples injected with the same conditions or with data published in the literature (Stenhagen et al. 1974 and Adams,2001)

Data were subjected for statistical analysis to calculate $F$ test at the 0.05 level of probability according to Snedecor and Cochran (1990).

\section{RESULTS AND DISCUSSION}

\section{Hump beetle Gibbium psylloids (Zemp.):}

The data given in Table (1) indicated that essential oil of chamomile decreased in all packages due to the long period of storage such as after three months. 
J. Agric. Sci. Mansoura Univ., 34 (10), October, 2009

1 
Abo-Donia, S. A. et al.

The percentage of oil reduction reached $11.1 \%$ and $27.8 \%$ for $1^{\text {st }}$ and $2^{\text {nd }}$ level of infestation, in cellophane bag respectively and $16.7 \%$ and $33.5 \%$ for the first and the second level of infestation, in glass bag respectively. While in cloth bag the percentage of reduction was $27.8 \%$ and $45.0 \%$ for $1^{\text {st }}$ and $2^{\text {nd }}$ level of infestation, respectively.

After six months, the decrease of essential oil continued with different degrees according to type of package. It ranged between $18.9 \%$ and $33.5 \%$ for $1^{\text {st }}$ and $2^{\text {nd }}$ level of infestation, respectively in cellophane bag and $27.8 \%$ and $44.4 \%$ for $1^{\text {st }}$ and $2^{\text {nd }}$ level of infestation, respectively in glass jar, while in both plastic and cloth bags it was $33.3 \%$ and $50.00 \%$ for $1^{\text {st }}$ and $2^{\text {nd }}$ level of infestation, in plastic and respectively $40.9 \%$ and $55.6 \%$ for $1^{\text {st }}$ and $2^{\text {nd }}$ level of infestation, respectively.

After nine months, the decrease of essential oil continued with different degrees according to type of package it ranged between $27.0 \%$ and $44.1 \%$ for $1^{\text {st }}$ and $2^{\text {nd }}$ level of infestation, respectively, in cellophane bag and $38.9 \%$ and $50.0 \%$ for $1^{\text {st }}$ and $2^{\text {nd }}$ level of infestation, respectively in glass jar while, in plastic jar it was $50.0 \%$ and $61.1 \%$ for $1^{\text {st }}$ and $2^{\text {nd }}$ level of infestation, respectively and in cloth bag it was $55.6 \%$ and $66.5 \%$ for $1^{\text {st }}$ and $2^{\text {nd }}$ level of infestation, respectively. The volatile oil percent in the flower heads of the different treatments as shown in Table (2). It is clear that the volatile oil percent decreased gradually in all kind of containers Table (2).

Table (2): Essential oil \% of Matricaria chamomilla as affected by storage containers.

\begin{tabular}{|c|c|c|c|c|c|c|c|c|c|c|c|c|}
\hline \multirow{2}{*}{$\begin{array}{c}\text { Containers } \\
\text { months }\end{array}$} & \multicolumn{3}{|c|}{ Plastic } & \multicolumn{3}{c|}{ Glass } & \multicolumn{3}{c|}{ clothes } & \multicolumn{3}{c|}{ Cellophane } \\
\cline { 2 - 13 } & control & $\begin{array}{c}\text { Semi } \\
\text { inf. }\end{array}$ & Inf. & Con. & $\begin{array}{c}\text { Semi } \\
\text { Inf. }\end{array}$ & Inf. & Control & $\begin{array}{c}\text { Semi } \\
\text { Inf. }\end{array}$ & Inf. & control & $\begin{array}{c}\text { Semi } \\
\text { Inf. }\end{array}$ & Inf. \\
\hline 0 & 0.18 & 0.18 & 0.18 & 0.018 & 0.18 & 0.18 & 0.18 & 0.18 & 0.18 & 0.18 & 0.18 & 0.18 \\
\hline 3 & 0.15 & 0.13 & 0.11 & 0.15 & 0.12 & 0.10 & 0.13 & 0.10 & 0.08 & 0.16 & 0.11 & 0.12 \\
\hline 6 & 0.14 & 0.11 & 0.09 & 0.13 & 0.10 & 0.08 & 0.10 & 0.09 & 0.07 & 0.14 & 0.13 & 0.11 \\
\hline 9 & 0.12 & 0.09 & 0.07 & 0.12 & & & 0.11 & 0.09 & 0.07 & 0.13 & 0.11 & 0.10 \\
\hline 12 & 0.10 & 0.08 & 0.06 & 0.10 & & & 0.09 & 0.08 & 0.06 & 0.13 & 0.10 & 0.09 \\
\hline Mean & 0.138 & 0.118 & 0.102 & 0.132 & & & 0.114 & 0.10 & 0.088 & 0.146 & 0.132 & 0.12 \\
\hline
\end{tabular}
Semi inf. = Semi infection
Inf. = infection

The containers varied in their decrements, cloth containers showed the highest decrement which may be explained in the view of that clothes have good aireation which increased the loss of volatile oil. Glass, cellophane and plastic containers showed the same rate of decrement with increasing storage period . infection with Gibbium psylloids decreased the content of volatile oil. Increasing the level of infection increased the loss of volatile oil from $0.08 \%$ to $0.11 \%$. This trend was clear in all kind of containers. Cellophane containers showed the lowest value of volatile oil decrement.There is a good correlation between numbers of insects and volatile oil content. It is clear that the number of insects increased with increasing the period of storage in all containers meanwhile it increased with decreasing the volatile oil on the number of insects. The results agree with those results obtained by Salama and Ahmed (1995); and Misra (1997) and Waffaa and Yousef(2001) on Chamomile. 
The main constituents of volatile oils of chamomile:

The main constituents of chamomile as separated and identified by GC / MS are shown in Table (3) accounted for more than $87.5 \%$ their molecular weights, formula and chemical structures are shown in the same table. Bisabodol Oxide- $A$ was found to be the main compound and accounted for $57.8 \%$ followed by bisanolol oxide-B (8.6\%), azulene, 7-ethyl$1,4$ dimethyl ( $8.6 \%)$, dicycloethers (8.7\%) and a-bisabolol which accounted for $1.6 \%$.

The main hydrocarbon was found to be farnesene and accounted for $0.8 \%$ the hydrocarbon monoterpens were identified as $\alpha$-pinene $(0.1 \%) B$ pinene $(0.04 \%)$ and p-cymene $(0.3)$, while anethole $(0.2 \%)$ is oxygenated monoterpine. The sesquterpeinic hydrocarbons are farnesene , a zulene- 7ethyle-1,4-dimethyl,y-candinene, while the oxygenated sesqterpines are bisabolol oxide-A \& B and $\alpha$ - bisabolol, and chamazlene, 7, ethyl1,4dimethyl1.

These results are in agreement with those of Youssef and Moussa (1998) who found that bisabolol oxide A ranged from 53.9 to $80.4 \%$ followed by bisabolol oxide $B$ which ranged from 33.5 to $50.9 \%$. On the other hand, chamazulene, bisabolol and farnesene were found as in low concentration or trace amounts. Felkova et al. (1981) Honcarive and Repcak (1979), and Wafaa and Yousef (2001).

Effect of storage treatments on the main constituents of volatile oils of chamomile:

Volatile oil of Chamomile showed the main component as bisabolol oxide $A$ in all treatment. Its relative percent reached $64 \%$ while other treatments showed its content with $40 \%$ Cis-Dicyclaether increased from 8.7 to $10.5 \%$ bisabolol oxide $B$ showed the same trend as that of bisabolol oxide A in which it decreased from 8.6 to $6.1 \%$.

The mean values of bisabolol oxide $A$ as affected by storage conditions and the storage period are shown in table (4). Generally in glass containers, The data showed no considerable differences according to storage period in glass containers.

In cloth containers bisabolol oxide A contenton flower head landed to decrease up to 9 months.

Bisabolol oxide-A of The mean valued as affected by storage containers and the storage period are showed in table (4). Flower heads content of bisabolol oxide-A tended to decrease up to nine months then increased to be more or less The same value of three months sample. 
Abo-Donia, S. A. et al.

Table (3): Molecular weights, chemical formulas and chemical of the volatile oil Matricaria chamomilla

\begin{tabular}{|c|c|c|c|c|}
\hline 7Compound & $\%$ & $\begin{array}{c}\text { Molecular } \\
\text { weights }\end{array}$ & $\begin{array}{l}\text { chemical } \\
\text { formulas }\end{array}$ & Structure \\
\hline$\alpha$-pinene & 0.11 & 136 & $\mathrm{C}_{10} \mathrm{H}_{16}$ & \\
\hline B-pinene & 0.04 & 136 & $\mathrm{C}_{10} \mathrm{H}_{16}$ & \\
\hline p-cymene & 0.29 & 134 & $\mathrm{C}_{10} \mathrm{H}_{14}$ & \\
\hline Anethole & 0.23 & 148 & $\mathrm{C}_{10} \mathrm{H}_{18} \mathrm{O}$ & \\
\hline Farnesene & 0.80 & 204 & $\mathrm{C}_{15} \mathrm{H}_{24}$ & \\
\hline B-cubebene & 0.17 & 204 & $\mathrm{C}_{15} \mathrm{H}_{24}$ & \\
\hline$y$-cadinene & 0.21 & 204 & $\mathrm{C}_{15} \mathrm{H}_{24}$ & \\
\hline Bisabolol oxide-B & 8.61 & 238 & $\mathrm{C}_{15} \mathrm{H}_{26} \mathrm{O}_{2}$ & \\
\hline a-Bisabolol & 1.55 & 222 & $\mathrm{C}_{15} \mathrm{H}_{26} \mathrm{O}$ & \\
\hline
\end{tabular}


J. Agric. Sci. Mansoura Univ., 34 (10):, 2009

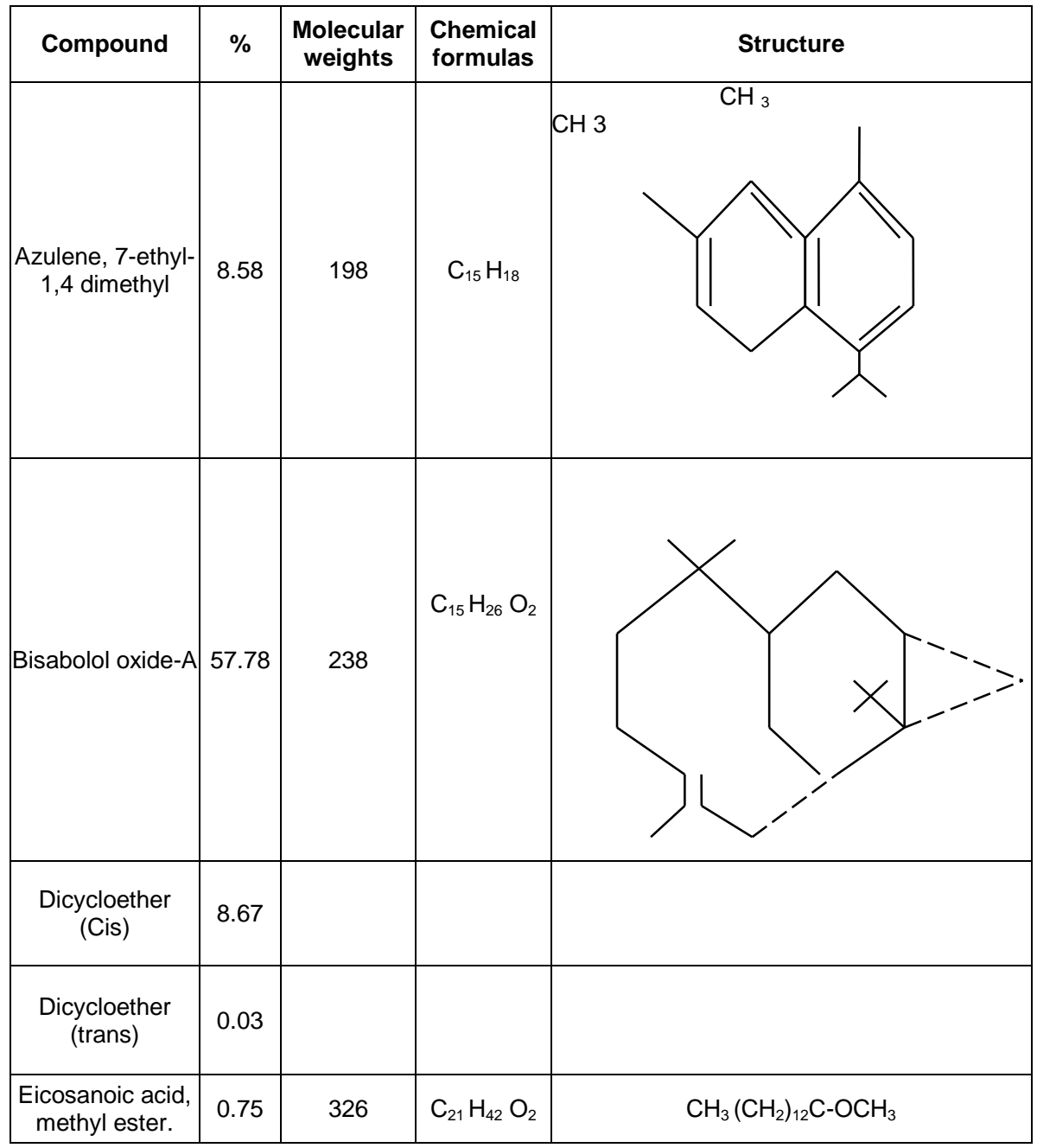

Table (4): Bisabolol oxide-A content in the volatile oil of Matricaria chamomila as affected by storage conditions .

\begin{tabular}{|c|c|c|c|c|}
\hline Month Containers & Plastic & Glass & Cloth & Cellophane \\
\hline 3 & 58 & 55.3 & 54.5 & 53.5 \\
\hline 6 & 55.6 & 57.1 & 55.2 & 54.1 \\
\hline 9 & 47.8 & 55.8 & 47.5 & 36.4 \\
\hline 12 & 57.9 & 58.0 & 53.0 & 50.6 \\
\hline
\end{tabular}

In glass containers, flower heads showed on considerable differences according to storage period in glass containers. In cloth containers, bisabolol oxide-A in flower heads tended to decrease in their content up to nine months. 
Abo-Donia, S. A. et al.

There results agree with of Waffaa (2001). In cellophane containers, bisabolol oxide-A content in the sample of nine months flower heads showed the minimum content of bisabolol oxide-A (36.4\%).

Effect of infestation on the content of bisabolol oxide-A:

The effect of infestation on the content of bisabolol oxide-A in the flower heads stored in different containers is shown in Table (5). It is clear that infestation and semi infestation flower heads contained higher percentage of bisabolol oxide-A comparing to control treatment in most containers.

Table (5): Effected of infestation with insects in different containers on bisabolol oxide - B content of Matricaria chamomila volatile oil.

\begin{tabular}{|c|c|c|c|c|}
\hline Containers & Plastic & Glass & Cloth & Cellophane \\
\hline Control & 12.8 & 15.5 & 15.3 & 14.0 \\
\hline Semi infected & 13.7 & 14.5 & 14.2 & 14.7 \\
\hline Infected & 13.3 & 14.2 & 11.4 & 15.31 \\
\hline
\end{tabular}

The flower heads stored at cloth showed the minimum content of bisabolol oxide-A I semi infested flower heads. bisabolol oxide-B contents in flower heads of chamomile as affected by storage containers as shown in Table (7).

Increasing storage period decreased bisabolol oxide-B contents flower heads stored in all kind of containers.

These may attributed to the conversion of bisabolol oxide $-B$ to other compounds.

The reduction of bisabolol oxide- $\mathrm{B}$ after 12 months reached more than $50 \%$ in flower heads stored at clothes as shown in Table (6).

Table (6): Bisabolol oxide-B contents in the volatile oil of Matricaria chamomila as affected by storage conditions .

\begin{tabular}{|c|c|c|c|c|}
\hline Month Containers & Plastic & Glass & Cloth & Cellophane \\
\hline 3 & 17.3 & 17.2 & 18.4 & 18.6 \\
\hline 6 & 14.3 & 15.1 & 13.6 & 13.7 \\
\hline 9 & 12.2 & 13.8 & 13.9 & 16.0 \\
\hline 12 & 9.3 & 12.9 & 8.7 & 10.4 \\
\hline
\end{tabular}

The contents of bisabolol oxide- $B$ in the volatile oil of flower heads of chamomile stored in different containers are showed in Table (7). In plastic containers, flower heads showed gradual increase in their contents of bisabolol oxide-B up to 12 months.

Table (7): Effected of infestation with insects in different containers on bisabolol oxide - A contents of Matricaria chamomila volatile oil.

\begin{tabular}{|c|c|c|c|c|}
\hline Containers & Plastic & Glass & Cloth & Cellophane \\
\hline Infection & 75.2 & 55.9 & 57.5 & 53.6 \\
\hline Control & 54.6 & 54.9 & 50.0 & 51.8 \\
\hline Infected & 61.2 & 57.0 & 54.9 & 51.4 \\
\hline
\end{tabular}


In glass and cloth containers, flower heads showed gradual decrease in their contents of bisabolol oxide-B up to 12 months. The same trend was observed with cellophane containers, in which the six months sample showed lower content of bisabolol oxide-B comparing to nine months sample.

\section{REFERENCES}

Adams, R. P. (2001): Identification of essential oil components by Gas Chromatography/ Tap Mass Spectrometry. Allured publishing Copoation, Caral Stream, IL.

Ahmed, S. K.; and El-Gamal, E. (1995): Cultivation of medicinal herbs at Madinatel- Hikmah, Hamdard Medicus, 39: (2) : 23-26.

Ahmed, A.; and Misra, L. N. (1997): Isolation of herniarin and other constituents from Matricaria chamomilla flowers. International Pharmacogenosy: a journal of crude drug Journal research. Vol.(2): $121-125$

Belles, X. and Holstead, D. G. H. (1985): Identification and geographical distribution of Gibbium aequinoctiole Boieldieu and Gibbium psylloides (Czemp) (Coleoptera : Ptinidae). J. Stored products Research. (21): 3. 151-155.

Bosman, B. T. and Jonge, J. I. (1998): Nuisance or pest mites and insects in and near buildings. Entomologische Berichten, 41 (6): 81-83.

Carle, R.; Dolle, B.; and Reinkard, E. ; (1989): An approach to the production of chamomile extracts plants Medica 55 (6): 540-543.

Chinenova.E. G. ; Zolodova, S. E.; Reingach, B. Y. A,; and

Titova, V. I. (1969): .Changes in components of essential oils during storage of spices . Dialog information servius Inc. U. S. A. 01406670$02 \mathrm{t} 0045$.

Felkova, M.; Gaficova, M.; Trnkova, L.; and Utti, G. (1981): Effect of miniral nutrition on the yield and quality of chamomile flowers Matricaria chamomilla cultivayions. Bochinia. Acta Facu. Pharm. Univ. Comevianae, 69-102.

Guenther, E .(1973): The essential oils. D.van Nostfend company, New York, Toronto, London.vol.I.

Honcariv, R.; and Repcak, M. (1979): Chemotypes of Matricaria chamomilla L. Herba Polonica, 25 (4) 261-267. C. F. Hort. Absr. 1981, Vol. 51, No. 2.

Hornok, L. (1992): Cultivation and processing of Medicinal plants. John Wiley \& Sons. New York, PP. $220-224$.

Lee, K. W.; Powdrs, N. R. and Walker, T. W. (1992): A preliminary survey of insects and mites associated with stored food products in korea. J. Entomol., 22 (1): 5-12.

Rakova, N. V. (1961): change of the asay of the essential oil upon storage of coriander seed. Spirt. Prosmt. 27, 13; (c. f. Chem., Abs. 55, 26375e.).

Refaat, A. M. (1988): Effect of fertilization levels methods of during and period of storage on the sweet marjoram Herb Yield and its active ingredients. Ph. D. Thesis , Faculty of agric., Ain Shams niversity, Egypt. 
Salama, R. A. K.; and Ahmed, Sh. K. (1995): Effect of post harvest treatments and infestation of Gibbium psylloids (CZEMP) (Ptinidea : Coleoptera) on the loss of quality and quantity of dry chamomile flowers heads. Bull. Ent. Soc. Egypt. 73, 209.

Snedecor, G. W.; and Cochran, W. G. (1990): "a statistical methods" $8^{\text {th }}$ Ed. lowa state Univ. Press Ames, lowa, U. S. A.

Stenhagen, E., Abrahamson, S. and Mclaffery, F. (1974): Registry of Mass Spectral Data. Wiley Sons Inc, New york.

Wafaa, M. A. Yousef (2001): Efficiency of Gamma Radition and storage methods on Gibbium psylloides (Czemp) and Plodia interpuncetella (Itbn.) Thesis doctor of philosophy in Economic Entomology. Cairo University. 2001.

Youssef, A. A. and Moussa, A. Z. (1998): Effect of gamma rays on growth and essential composition of chamomile (Chamomillia recutita L.). Ara. Univ. J. Agric. Sci. Ain-Shams Univ., Cairo, Vol. 6 (2): 301-311.

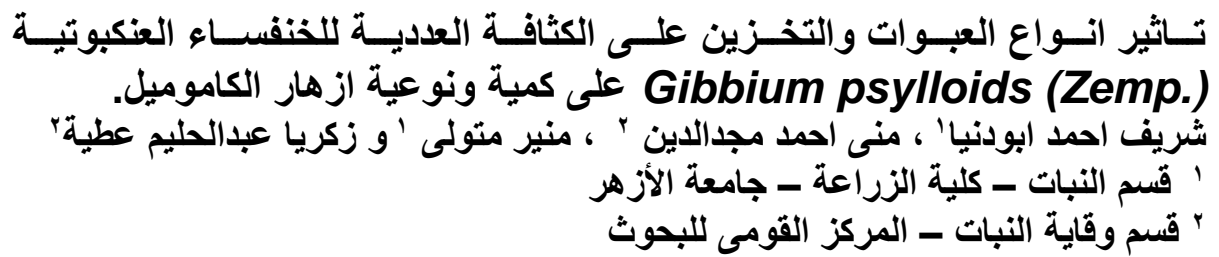

Gibbium psylloids تاثثير معاملات ما بعد الحصاد وكذللك الخنفساء العنكبوتية

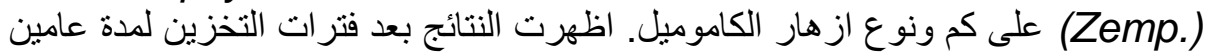

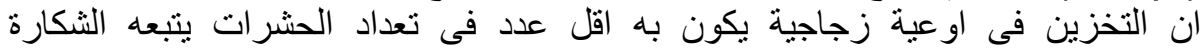

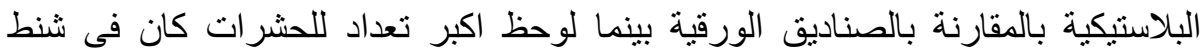

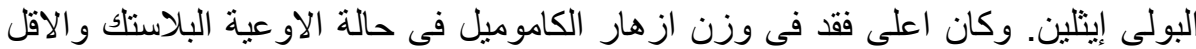

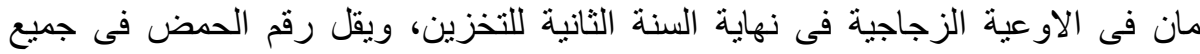
العبوات فيما عدا عبوات البولى ايثلين الذى سجل زيادة في رقم الحمض بعد رفئ عامين للزيت فيت الطيار. 
J. Agric. Sci. Mansoura Univ., 34 (10), October, 2009 
J. Agric. Sci. Mansoura Univ., 34 (10):, 2009

Table (1): Mean insect numbers of Gibbium psylloids, and reduction percentage of oil at different type of package throughout one year of chamomile .

\begin{tabular}{|c|c|c|c|c|c|c|c|c|c|c|c|}
\hline \multirow{2}{*}{$\begin{array}{l}\text { Storage } \\
\text { period }\end{array}$} & \multirow{2}{*}{\begin{tabular}{|c|} 
Level of \\
infestation
\end{tabular}} & \multicolumn{4}{|c|}{ Mean insect number } & \multirow{2}{*}{ Mean } & \multirow{2}{*}{$\begin{array}{c}\text { General } \\
\text { mean }\end{array}$} & \multicolumn{4}{|c|}{ Oil reduction } \\
\hline & & Plastic & Glass & Cloth & Cellophane & & & Plastic & Glass & Cloth & Cellophane \\
\hline \multirow{2}{*}{3} & & $74.7 \pm 1.00$ & $65.0 \pm 1.15$ & $85.7 \pm 1.73$ & $43.0 \pm 2.30$ & 67.1 & \multirow{2}{*}{$\begin{array}{c}87.1 \\
\text { (d) }\end{array}$} & 22.2 & 16.7 & 27.8 & 11.1 \\
\hline & III & $114.3 \pm 2.51$ & $105.0 \pm 2.88$ & $138.0 \pm 2.90$ & $71.0 \pm 3.05$ & 107.1 & & 38.9 & 33.5 & 45.0 & 27.8 \\
\hline \multirow{2}{*}{6} & T & $115.3 \pm 8.66$ & $90.3 \pm 2.89$ & $164.3 \pm 2.29$ & $66.7 \pm 5.77$ & 109.2 & \multirow{2}{*}{$\begin{array}{c}145.7 \\
\text { (c) }\end{array}$} & 33.3 & 27.8 & 40.9 & 18.9 \\
\hline & III & $225 \pm 1.15$ & $145.0 \pm 6.24$ & $246 \pm 4.61$ & $113 \pm 7.63$ & 182.3 & & 50.0 & 44.4 & 55.6 & 33.5 \\
\hline \multirow{2}{*}{9} & I & $201.3 \pm 8.66$ & $110.3 \pm 6.22$ & $222.7 \pm 3.06$ & $84.5 \pm 2.30$ & 154.6 & \multirow{2}{*}{$\begin{array}{l}220.1 \\
\text { (b) }\end{array}$} & 50.0 & 38.9 & 55.6 & 27.0 \\
\hline & III & $331.0 \pm 2.00$ & $194.3 \pm 2.88$ & $460.0 \pm 4.61$ & $157 \pm 7.50$ & 185.6 & & 61.1 & 50.0 & 66.5 & 44.1 \\
\hline \multirow[b]{2}{*}{12} & I & $321.0 \pm 5.00$ & $145.3 \pm 4.6$ & $337.7 \pm 14.43$ & $112.3 \pm 8.81$ & 229.1 & \multirow{2}{*}{$\begin{array}{c}313.7 \\
\text { (a) }\end{array}$} & 55.6 & 44.4 & 61.1 & 33.8 \\
\hline & III & 504.33 .05 & $252 \pm 3.46$ & $639 \pm 13.22$ & $198 \pm 8.66$ & 390.3 & & 66.7 & 58.6 & 72.2 & 50.0 \\
\hline \multicolumn{2}{|c|}{ General mean Group } & $\begin{array}{l}235.9 \\
\text { (a) }\end{array}$ & $\begin{array}{c}138.4 \\
\text { (C) }\end{array}$ & $\begin{array}{c}286.7 \\
\text { (b) }\end{array}$ & $\begin{array}{c}105.6 \\
\text { (d) }\end{array}$ & $\begin{array}{c}\mathrm{F} \\
\text { (period) }\end{array}$ & 1779.84 & & & & \\
\hline \multirow{2}{*}{\multicolumn{2}{|c|}{\begin{tabular}{|l|} 
F. S. D. \\
L.
\end{tabular}}} & 1313.49 & & & & & & & & & \\
\hline & & 6.6 & & & & 0.5 & 6.6 & & & & \\
\hline
\end{tabular}

I test (1\& \& 11) $9.44^{*}$

II Second level of infestation

T test (I8II) $9.44^{\star}$ 